\title{
Bcl-2 Inhibitor APG 2575
}

National Cancer Institute

\section{Source}

National Cancer Institute. BCl-2 Inhibitor APG 2575. NCI Thesaurus. Code C156249.

An orally bioavailable and selective inhibitor of the anti-apoptotic protein B-cell lymphoma

2 (Bcl-2), with potential pro-apoptotic and antineoplastic activities. Upon oral administration, $\mathrm{Bcl}-2$ inhibitor APG 2575 targ ets, binds to and inhibits the activity of $\mathrm{BCl}-2$. This restores apoptotic processes in tumor cells. $\mathrm{Bcl}-2$ is overexpressed in many cancers and plays an important role in the negative regulation of apoptosis; its expression is associated with increased drug resistance and tumor cell survival. 